\title{
Sistem Pakar Diagnosa Penyakit Daun Dan Batang Pada Tanaman Karet Menggunakan Metode Certainty Factor Berbasis WEB
}

\author{
Endah Sri Wahyuni \\ Politeknik Pertanian Negeri \\ Samarinda Teknologi Rekayasa \\ Perangkat Lunak Manajemen \\ Pertanian \\ Samarinda, Kalimantan Timur \\ yabukota96@gmail.com
}

\author{
Dwi Arief Prambudi \\ Teknologi Rekayasa Perangkat \\ Lunak \\ Politeknik Pertanian Negeri \\ Samarinda Manajemen Pertanian \\ Samarinda, Kalimantan Timur \\ prambudiariefdwi@gmail.com
}

\author{
Roby \\ Teknologi Rekayasa Perangkat \\ Lunak \\ Politeknik Pertanian Negeri \\ Samarinda Manajemen Pertanian \\ Samarinda, Kalimantan Timur \\ robybtp1@gamil.com
}

\begin{abstract}
Abstrak - Tanaman karet adalah tanaman tahunan yang dapat tumbuh sampai umur 30 tahun. Habitus tanaman ini merupakan pohon dengan tinggi tanaman dapat mencapai 15 - 20 meter. Modal utama dalam pengusahaan tanaman ini adalah batang setinggi 2,5 sampai 3 meter dimana terdapat pembuluh latek. Oleh karena itu fokus pengelolaan tanaman karet ini adalah bagaimana mengelola batang tanaman ini seefisien mungkin. Sistem Pakar adalah sebuah sistem yang menggunakan pengetahuan manusia dimana pengetahuan tersebut dimasukkan ke dalam sebuah komputer dan kemudian digunakan untuk menyelesaikan masalah-masalah yang biasanya membutuhkan kepakaran atau keahlian manusia. Salah satu penerapan sistem pakar adalah dalam bidang perkebunan untuk mendiagnosa penyakit pada tanaman. Pada penelitian ini dilakukan perancangan dan pembuatan sistem pakar yang digunakan untuk membantu mendiagnosa suatu penyakit daun dan batang pada tanaman karet serta menentukan solusi terhadap tanaman karet Dari penjelasan di atas untuk itu penulis membuat suatu sistem, yaitu sistem pakar diagnosa penyakit daun dan batang pada tanaman karet menggunakan metode certainty factor yang dimaksudkan untuk membantu kerja petani dalam memberikan informasi serta kesimpulan dari penyakit daun dan batang yang diderita pada tanaman karet.
\end{abstract}

Kata Kunci-Sistem Pakar, Certainty Factor, Penyakit Tanaman Karet.

\section{PENDAHULUAN}

Perkembangan teknologi informasi khususnya peranan kecerdasan buatan (Artificial Intelengence) pada aktifitas manusia saat ini, memiliki pengaruh sangat besar dikarenakan banyak sekali kemudahan yang didapat dalam menerapkan teknologi kecerdasan buatan. Salah satunya adalah dengan menerapkan sistem pakar. Dengan menerapkan sistem pakar, sebuah program akan memodelkan kemampuan dalam menyelesaikan masalah seperti layaknya seorang pakar sehingga didapatkan efisiensi dan efektifitas dalam mendapatkan sebuah solusi dari permasalahan yang ada(Heminsyah,2013).

Karet (Hevea brasiliensis Muell. Arg) merupakan komoditas perkebunan yang sangat penting peranannya di Indonesia. Areal perkebunan karet di Indonesia pada tahun 2012 mencapai 3,4 juta hektar. Dari total perkebunan karet tersebut luasan perkebunan dibagi seluas 29 juta hektar atau $85 \%$ merupakan Perkebunan Rakyat (PR) dan selebihnya Perkebunan Besar Negara (PBN) dan Perkebunan Besar Swasta (PBS) (Jenderal Perkebunan Kementrian Pertanian, 2013). Beberapa Perkebunan Besar Negara maupun Perkebunan Besar Swasta sudah mempunyai laporan intensitas serangan penyakitdengan disertai peta sebarannya, namun sejauh ini belum diterapkan pada perkebunan rakyat, hal ini dikarenakan para petani tidak mendapatkan informasi adanya serangan penyakit di kebun mereka sehingga penyebaran penyakit JAP(Jamur Akar Putih) pada kebun rakyat masih lebih cepat menyebar(Rahayu, Lubis \& Omery,2017).

Oleh karena itu dibutuhkan sebuah metode atau aturan untuk menyelesaikan masalah penyakit karet tersebut yaitu dengan metode certainty factor. Metode certainty factor merupakan metode yang mendefinisikan ukuran kepastian terhadap masalah yang sedang dihadapi dengan menggunkan certainty factor ini dapat menggambarkan tingkat keyakinan pakar(Miranda, Hasibuan, Pristiwanto \& Mesran,2016).

Berdasarkan uraian latar belakang diatas, maka permasalahan yang akan dibahas dalam penulisan skripsi ini yaitu bagaimana mengenali dan mengetahui gejala penyakit daun dan batang pada tanaman karet dan solusi penanganannya dengan mengunakan sistem pakar.

\section{TINJAUAN PUSTAKA}

\section{A. Kajian Ilmiah}

Beberapa literatur yang digunakan sebagai pedoman dan acuan dalam Tugas Akhir ini antara lain :

1. Menurut Mujilawati (2014) dalam penelitian yang berjudul sistem pakar penyakit tanaman hias menggunakan metode Certainty Factor Berbasis Web yang diharapkan dapat digunakan sebagai 
penyedia solusi terhadap tanaman yang sudah terkena penyakit..

2. Menurut Zainab (2017) dalam penelitian yang berjudul Sistem Pakar Diagnosa Penyakit Pada Tanaman Karet Menggunakan Metode Certainty Factor, yang dapat ditujukan sebagai penyedia nasehat dan sarana bantu dalam memecahkan masalah.

3. Menurut penelitian yang dilakukan Irwan (2016) dalam penelitiannya yang berjudul Aplikasi Sistem Pakar Identifikasi Penyakit Pada Tanaman Padi Menggunakan Metode Certainty Factor, yang dapat ditujukan untuk membantu para petani mengendalikan penyakit pada tanaman padi.

4. Menurut Maulana, Fitriyadi, dan Fitriani (2016) dalam penelitian yang berjudul Sistem Pakar Diagnosis Penyakit Tanaman Karet Dengan Metode Dempester-Shafer, untuk mendapatkan nilai kepastian dari suatu gejala yang dialami pada tanaman karet terhadap suatu penyakit.

5. Menurut penelitian yang dilakukan Anshori (2018) dengan penelitian yang berjudul Sistem Pakar Untuk Menentukan Pola Latihan Fitness Menggunakan Metode Certainty Factor. Dalam penelitian ini bermaksud untuk menghitung jumlah kebutuhan kalori yang dibutuhkan oleh seorang untuk perhari dan menentukan pola latihan fitess yang tepat agar tidak ada kekeliruan lagi dalam menentukan pola latihan yang benar.

Perbedaan penelitian yang dilakukan dengan peneliti sebelumnya adalah menggunakan Sistem Pakar Diagnosa Penyakit Daun dan Batang pada Tnaman Karet Menggunakan metode Certainty Factor berbasis web, sistem dibangun menggunakan bahasa Pemrograman PHP dan XAMPP.

\section{B. Sistem Pakar}

Sistem pakar (Expert System) dibuat bertujuan untuk dapat menyelesaikan masalah yang cukup rumit yang sebenarnya hanya bisa diselesaikan oleh para ahli. Pembuatan sistem pakar bukan untuk menggantikan ahli itu sendiri melainkan dapat digunakan sebagai asisten yang sangat berpengalaman (Kusumadewi, 2003).

\section{Certainty Factor}

Certainty factor merupakan suatu metode yang digunakan untuk memecahkan permasalahan dari jawaban yang tidak pasti, dan menghasilkan jawaban yang tidak pasti pula. Ketidak pastian ini dipengaruhi oleh dua faktor yaitu aturan yang tidak pasti dan jawaban pengguna yang tidak pasti. Contoh paling mudah dari penggunaan metode ini adalah pada kasus penentuan penyakit dengan gejala-gejala yang sudah ditentukan. Aturan yang tidak pasti pada kasus ini adalah aturan gejala-gejala yang ditentukan untuk suatu penyakit. Satu gejala dapat berada dibeberapa penyakit, dalam artian satu penyakit memiliki gejala yang sama dengan penyakit yang lain, inilah yang disebut dengan aturan yang tidak pasti. Kemudian saat pengguna memberikan jawaban atas pertanyaan yang diberikan oleh sistem, pengguna juga tidak tahu persis gejala terjadi pada tubuhnya. Sehingga dari ketidak pastian tersebut, diberikan jembatan agar kedua faktor ketidak pastian tersebut tidak terlalu jauh dari perkiraan atau kemungkinan yang terjadi. Jembatan penghubung kedua faktor tersebut adalah sebuah nilai, dimana nilai dari satu gejala maupun jawab mempunyai besaran nilai yang berbeda. Nilai inilah yang mengubah dari ketidak pastian menjadi kepastian. Paling tidak mendekati nilai pasti

Certainty factor menggunakan suatu nilai untuk mengasumsi derajad keyakinan seorang pakar terhadap suatu data. Formula dasar digunakan apabila belum ada nilai CF untuk setiap gejala yang menyebabkan penyakit. Kombinasi certainty factor yang digunakan untuk mengdiagnosa penyakit adalah:

a. Certainty Factor untuk kaidah dengan premis/gejala tunggal (single premis rules):

$\mathrm{CF}_{\text {gejala }}=\mathrm{CF}$ [user $] * \mathrm{CF}$ [pakar]

b. Apabila terdapat kaidah dengan kesimpulan yang serupa (similiary concluded rules) atau lebih dari satu gejala, maka CF selanjutnya dihitung dengan persamaan: $\mathrm{CF}_{\text {combine }}=\mathrm{CF}_{\text {old }}+\mathrm{CF}_{\text {gejala }} *\left(1-\mathrm{CF}_{\text {old }}\right)$

c. Sedangkan untuk menghitung persentase terhadap penyakit, digunakan persamaan:

$\mathrm{CF}_{\text {persentase }}=\mathrm{CF}_{\text {combane }} * 100$

\section{Tanaman Karet}

Karet merupakan komoditi ekspor yang mampu memberikan kontribusi di dalam upaya peningkatan devisa Indonesia. Ekspor Karet Indonesia selama 20 tahun terakhir terus menunjukkan adanya peningkatan dari 1.0 juta ton pada tahun 1985 menjadi 1.3 juta ton pada tahun 1995 dan 1.9 juta ton pada tahun 2004. Pendapatan devisa dari komoditi ini pada tahun 2004 mencapai US\$ 2.25 milyar, yang merupakan 5\% dari pendapatan devisa non-migas.

Table 1. Penyakit Daun

\begin{tabular}{|c|c|c|}
\hline No & Penyakit & Gejala \\
\hline 1 & $\begin{array}{l}\text { Penyakit Embun } \\
\text { Tepung }\end{array}$ & $\begin{array}{l}\text { Gejala penyakit ini adalah daun } \\
\text { muda berwarna hitam, lemas, } \\
\text { keriput dan seperti berlendir }\end{array}$ \\
\hline 2 & $\begin{array}{l}\text { Penyakit } \\
\text { Colletotrichum }\end{array}$ & $\begin{array}{l}\text { Gejala penyakit ini adalah daun } \\
\text { muda tampak lemas berwarna } \\
\text { hitam, keriput, bagian ujungnya } \\
\text { mati dan menggulung }\end{array}$ \\
\hline 3 & $\begin{array}{l}\text { Penyakit } \\
\text { Phytophtora }\end{array}$ & $\begin{array}{l}\text { Gejala penyakit ini adalah awal } \\
\text { tampak pada buah yang berwarna } \\
\text { hitam dan membusuk }\end{array}$ \\
\hline 4 & $\begin{array}{l}\text { Penyakit } \\
\text { Corynespora }\end{array}$ & $\begin{array}{l}\text { Gejala penyakit ini adalah daun } \\
\text { muda tampak bercak hitam seperti } \\
\text { menyirip kemudian lemas, pucat } \\
\text { dan ujungnya mati serta } \\
\text { menggulung }\end{array}$ \\
\hline 5 & $\begin{array}{l}\text { Penyakit } \\
\text { Helminthosporium }\end{array}$ & $\begin{array}{l}\text { Gejala penyakit ini adalah mula- } \\
\text { mula daun muda menjadi hitam } \\
\text { dan menggulung demudian gugur, } \\
\text { daun yang dewasa berbintik } \\
\text { coklat lambat laun membesar dan } \\
\text { berbentuk bundar }\end{array}$ \\
\hline
\end{tabular}


Table 2. Penyakit Batang

\begin{tabular}{|c|c|c|}
\hline No & Penyakit & Gejala \\
\hline 1 & Jamur Upas & $\begin{array}{l}\text { Gejala penyakit ini adalah pada } \\
\text { pangkal percabangan akan tampak } \\
\text { benang-benang putih seperti sutera } \\
\text { dan akhirnya berubah menjadi } \\
\text { warna merah tua, lateksnya akan } \\
\text { berwarna coklat kehitaman, kulit } \\
\text { tanaman membusuk dan berubah } \\
\text { menjadi hitam, mengering dan } \\
\text { terkelupas. }\end{array}$ \\
\hline 2 & Kanker Bercak & $\begin{array}{l}\text { Gejala Penyakit ini adalah bila } \\
\text { kulit batang atau cabang dikerok } \\
\text { kulit yang sakit baru tampak, } \\
\text { berwarna coklat kemerahan } \\
\text { dengan bercak-bercak besar yang } \\
\text { tampak meluas kesamping, } \\
\text { cambium dan bagian kayu, pada } \\
\text { bagian yang sakit biasanya keluar } \\
\text { cairan latek berwarna coklat } \\
\text { kemerahan dan berbau busuk. }\end{array}$ \\
\hline 3 & $\begin{array}{l}\text { Penyakit Busuk } \\
\text { Pangkal Batang }\end{array}$ & $\begin{array}{l}\text { Gejala penyakit ini adalah pada } \\
\text { "kaki gajah" tampak kulitnya } \\
\text { kering dan pecah-pecah sedangkan } \\
\text { kayu bagian atas masih baik dan } \\
\text { utuh, lambat laun kulit tersebut } \\
\text { menjadi hitam, bagian kayunya } \\
\text { rusak, akhirnya kerusakan } \\
\text { menjalar ke atas diikuti dengan } \\
\text { kerusakan bagian kayu. }\end{array}$ \\
\hline
\end{tabular}

\section{METODE PENELITIAN}

\section{A. Metode Penelitian}

Metode yang digunakan dalam pembuatan aplikasi sistem pakar diagnosa penyaki daun dan batang pada tanaman karet adalah metode certainty factor. Metode ini merupakan metode yang sering digunakan oleh penganalisa sistem pada umumnya. Inti dari metode Certainty Factor adalah suatu metode untuk membuktikan apakah suatu fakta itu pasti ataukah tidak pasti yang berbentuk metric yang biasanya digunakan dalam sistem pakar. Metode ini sangat cocok untuk sistem pakar yang mendiagnosis sesuatu yang belum pasti..

\section{B. Prosedur Penelitian}

Penelitian adalah suatu suatu proses yang disusun secara sistematis untuk yang dilakukan dengan berpedoman pada metode - metode ilmiah yang ada. (Emzir,2012) dan Menurut Muhammad Ali (2000) "Prosedur adalah tata cara kerja atau cara menjalankan suatu pekerjaan".

Jadi dapat kita simpulkan bahwa prosedur penelitian umum adalah suatu rangkaian, susunan, tata cara ataupun suatu proses yang secara umum digunakan dalam melakukan sebuah penelitian.

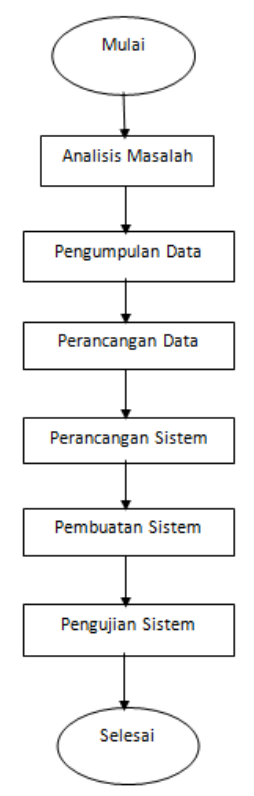

Gambar 1. Prosedur Penelitian

\section{Nilai Gejala}

Berikut merupakan nilai gejala yang di tentukan oleh pakar yaitu:

Table 3. Nilai Gejala

\begin{tabular}{|c|c|c|}
\hline No & Nama Gejala & $\begin{array}{c}\mathrm{CF} \\
\text { Bobot }\end{array}$ \\
\hline G001 & Apakah daun muda berwarna hitam? & 0.25 \\
\hline G002 & Apakah daun muda menjadi lemas? & 0.3 \\
\hline G003 & $\begin{array}{l}\text { Apakah dibawah permukaan daun } \\
\text { terdapat bercak bercak bundar berwarna } \\
\text { putih seperti tepung halus yang terjadi } \\
\text { dari benang benang hifa dan spora } \\
\text { jamur? }\end{array}$ & 0.8 \\
\hline G004 & Apakah daun muda menjadi keriput? & 0.6 \\
\hline G005 & $\begin{array}{l}\text { Apakah bagian daun ujung mati dan } \\
\text { menggulung dan gugur? }\end{array}$ & 0.5 \\
\hline G006 & $\begin{array}{l}\text { Apakah daun tua tampak bercak cokelat } \\
\text { atau hitam kemudian menjadi lubang } \\
\text { dan keriput serta sebagian ujungnya } \\
\text { mati? }\end{array}$ & 0.8 \\
\hline G007 & $\begin{array}{l}\text { Apakah bagian ujung daun mati dan } \\
\text { menggulung? }\end{array}$ & 0.6 \\
\hline G008 & $\begin{array}{l}\text { Apakah bagian daun ujung mati dan } \\
\text { menggulung? }\end{array}$ & 0.6 \\
\hline G009 & Apakah buah membusuk? & 0.8 \\
\hline G010 & $\begin{array}{l}\text { Apakah daun bercak hitam seperti } \\
\text { menyirip? }\end{array}$ & 0.7 \\
\hline G011 & Apakah daun muda menjadi pucat? & 0.7 \\
\hline G012 & $\begin{array}{l}\text { Apakah daun berbercak hitam dan } \\
\text { menyirip tetapi lebih jelas? }\end{array}$ & 0.8 \\
\hline G013 & $\begin{array}{l}\text { Apakah daun yang dewasa berbintik } \\
\text { bintik cokelat lambat laun membesar dan } \\
\text { berbentuk bundar? }\end{array}$ & 0.8 \\
\hline G014 & $\begin{array}{l}\text { Apakah pada tingkat serangan } \\
\text { awal,hanya terdapat lapisan jamur yang } \\
\text { tipis dan berwarna putih dipermukaan } \\
\text { kulit? }\end{array}$ & 0.9 \\
\hline G015 & $\begin{array}{l}\text { Apakah terbentuk lapisan kerak } \\
\text { berwarna merah muda yang disebut } \\
\text { dengan tingkat corticium dan jamur } \\
\text { sudah masuk ke dalam kayu? }\end{array}$ & 0.9 \\
\hline
\end{tabular}


G016

Apakah bila kulit batang atau cabang di

0.9

kerok kulit yang sakit baru tampak

berwarna cokelat kemerahan dan bercak

bercak besar yang tampak meluas

kesamping dan cambium dan bagian

kayu pada bagian yang sakit biasanya

keluar cairan lateks berwarna cokelat

kemerahan dan berbau busuk?

G017 Apakah kulit tampak kering dan pecahpecah?

Table 4. Certainty Factor (CF) evidence

\begin{tabular}{clc}
\hline No & USERTAIN TERM & NILAI CF EVIDENCE \\
\hline 1 & Sangat Tidak Yakin & 0 \\
2 & Tidak Yakin & 0.2 \\
3 & Kurang Yakin & 0.4 \\
4 & Cukup Yakin & 0.6 \\
5 & Yakin & 0.8 \\
6 & Sangat Yakin & 1 \\
\hline
\end{tabular}

Proses pemberian nilai CF pada setiap gejala hingga perolehan presentase keyakinan untuk penyakit Colletotrichum.

IF Apakah daun muda menjadi keriput? (Gejala 1)

AND Bagian daun ujung mati dan menggulung dan gugur? (Gejala 2)

AND Daun tua tampak bercak cokelat atau hitam kemudian menjadi lubang dan keriput serta sebagian ujungnya mati (Gejala 3)

AND Pada bagian daun ujung mati dan menggulung? (Gejala 4)

THEN Penyakit penyakit Colletotrichum

Langkah pertama, pakar menentukan nilai CF untuk masing-masing gejala. Adapun nilai $\mathrm{CF}$ yang diberikan pakar misalnya:

$$
\begin{array}{lll}
\mathrm{CF}_{\text {pakar }}(\text { Gejala }) & = & 0.6 \\
\mathrm{CF}_{\text {pakar }}(\text { Gejala }) & = & 0.5 \\
\mathrm{CF}_{\text {pakar }}(\text { Gejala }) & = & 0.8 \\
\mathrm{CF}_{\text {pakar }}(\text { Gejala } 4) & = & 0.6
\end{array}
$$

\begin{tabular}{|c|c|c|c|c|}
\hline Gejala 1 & $=$ & Yakin & $=$ & 0. \\
\hline Gejala 2 & $=$ & Cukup Yakin & $=$ & 0. \\
\hline Gejala 3 & $=$ & Sangat Yakin & $=$ & 1 \\
\hline Gejala 4 & $=$ & Tidak Yakin & $=$ & 0. \\
\hline
\end{tabular}

Misalkan user memilih jawaban sebagai berikut:

Proses perhitungan manual untuk kaidah 1:

$$
\begin{aligned}
\mathrm{CF}_{\text {gejala1 }} & =\mathrm{CF} \text { (user)* } \mathrm{CF} \text { (pakar) } \\
& =0.6 * 0.8 \\
& =0.48
\end{aligned}
$$

Proses perhitungan manual untuk kaidah 2:

$$
\begin{aligned}
\mathrm{CF}_{\text {gejala2 }} & =\mathrm{CF}(\text { user }) * \mathrm{CF} \text { (pakar) } \\
& =0.5 * 0.6 \\
& =0.3
\end{aligned}
$$

Proses perhitungan manual untuk kaidah 3:

$$
\begin{aligned}
\mathrm{CF}_{\text {gejala3 }} & =\mathrm{CF} \text { (user)* } \mathrm{CF} \text { (pakar) } \\
& =0.8 * 1
\end{aligned}
$$

$=0.8$

Proses perhitungan manual untuk kaidah 4:

$$
\begin{aligned}
\mathrm{CF}_{\text {gejala4 }} & =\mathrm{CF}(\text { user }) * \mathrm{CF} \text { (pakar) } \\
& =0.6 * 0.2 \\
& =0.12
\end{aligned}
$$

Dikarenakan terdapat lebih dari satu gejala, maka menentukan $\mathrm{CF}$ penyakit selanjutnya digunakan perhitungan:

$$
\begin{aligned}
& \mathrm{CF}_{\text {combine } 1}\left(\mathrm{CF}_{\text {gejala1 }}, \quad=\mathrm{CF}_{\text {gejala1 }}+\mathrm{CF}_{\text {gejala2 }} *(1-\right. \\
& \left.\mathrm{CF}_{\text {gejala2 }}\right) \\
& \left.\mathrm{CF}_{\text {gejala1 }}\right) \\
& =0.48+0.3 *(1-0.48) \\
& \mathrm{CF}_{\text {old } 1} \\
& \mathrm{CF}_{\text {combine } 2}\left(\mathrm{CF}_{\text {old } 1}\right. \text {, } \\
& \left.\mathrm{CF}_{\text {gejala3 }}\right) \\
& =0.8+0.3 * 0.52 \\
& =0.636 \\
& =\mathrm{CF}_{\text {old } 1}+\mathrm{CF}_{\text {gejala } 3} *(1- \\
& \mathrm{CF}_{\text {old1 } 1} \text { ) } \\
& =0.636+0.8 *(1-0.636 \\
& \text { ) } \\
& =0.636+0.8 * 0.364 \\
& \mathrm{CF}_{\text {old } 2} \\
& \mathrm{CF}_{\text {combine3 }}\left(\mathrm{CF}_{\text {old2 }}\right. \text {, } \\
& \left.\mathrm{CF}_{\text {gejala4 }}\right) \\
& =0.9272 \\
& =\mathrm{CF}_{\text {old2 }}+\mathrm{CF}_{\text {gejala } 4} *(1- \\
& \mathrm{CF}_{\text {old } 2} \text { ) } \\
& =0.9272+0.12 *(1- \\
& 0.9272 \text { ) } \\
& =0.9272+0.12 * 0.0728
\end{aligned}
$$

Keterangan: Old (symbol perhitungan sistem pakar setelah dicombine). CF old terakhir merupakan $\mathrm{CF}$ penyakit, berdasarkan hasil perhitungan $\mathrm{CF}$ diatas, maka $\mathrm{CF}$ penyakit adalah 0.935936, selanjutnya hitung presentase keyakinan terhadap penyakit dengan perhitungan:

Persentase

$$
\begin{aligned}
& =\mathrm{CF}_{\text {penyakit }} * 100 \\
& =0.935936 * 100 \\
& =93.5936 \%
\end{aligned}
$$

Berdasarkan hasil perhitungan, maka keterangan tingkat keyakinan berdasarkan table interpresentasi adalah HAMPIR PASTI.

\section{HASIL DAN PEMBAHASAN}

\section{A. Hasil}

Berikut ini merupakan tampilan hasil dan pembahasan dari aplikasi Sistem Pakar Diagnosa Penyakit Daun dan Batang Pada Tanaman Karet Menggunakan Metode Certainty Factor Berbasis Web. Aplikasi dibuat untuk mempermuda para petani karet untuk mengecek penyakit pada daun dan batang pada tanaman karet.

\section{1) Halaman Utama}

Menu utama adalah tampilan yang menampilkan penjelasan sistem pakar dan muncul pertama. 


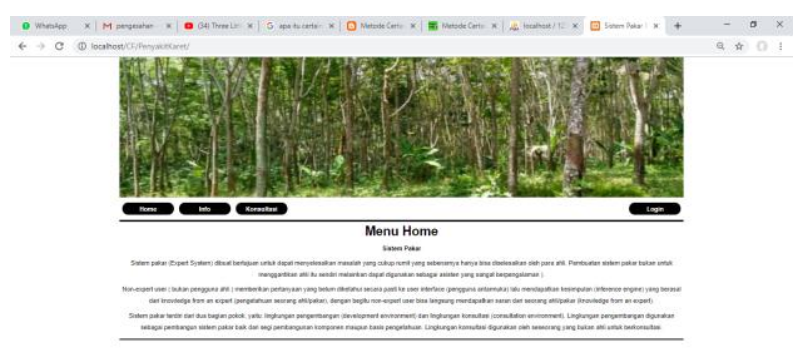

Gambar 2. Menu Utama

\section{2) Halaman Login}

Tampilan login adalah menampilkan tampilan halaman login untuk admin melakukan konsultasi.
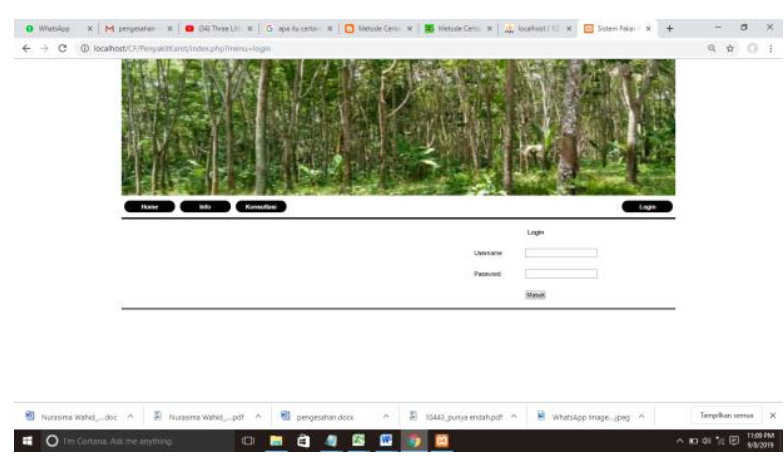

Gambar 3. Tampilan Login

\section{3) Tampilan Info}

Tampilan info adalah menampilkan tampilan info tanaman karet jenis penyakit daun dan jenis penyakit batang.

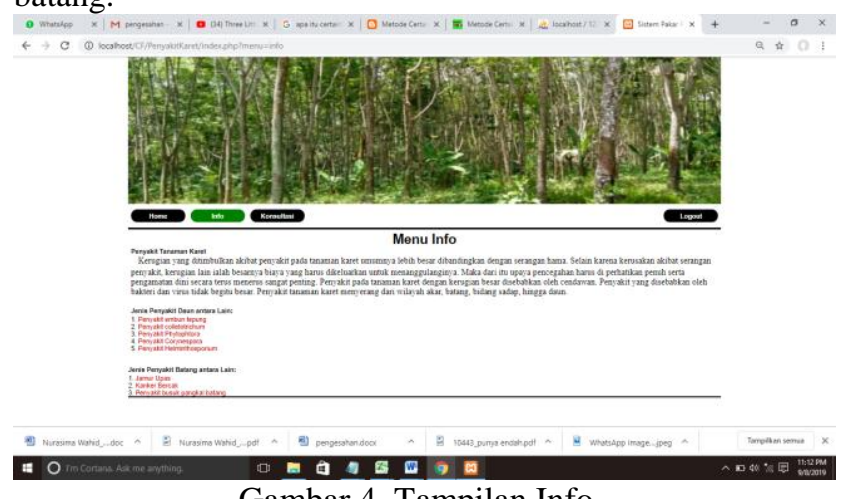

Gambar 4. Tampilan Info

\section{4) Tampilan Konsultasi}

Tampilan konsultasi adalah menampilkan tampilan untuk konsultasi yang berupa pertanyaan.

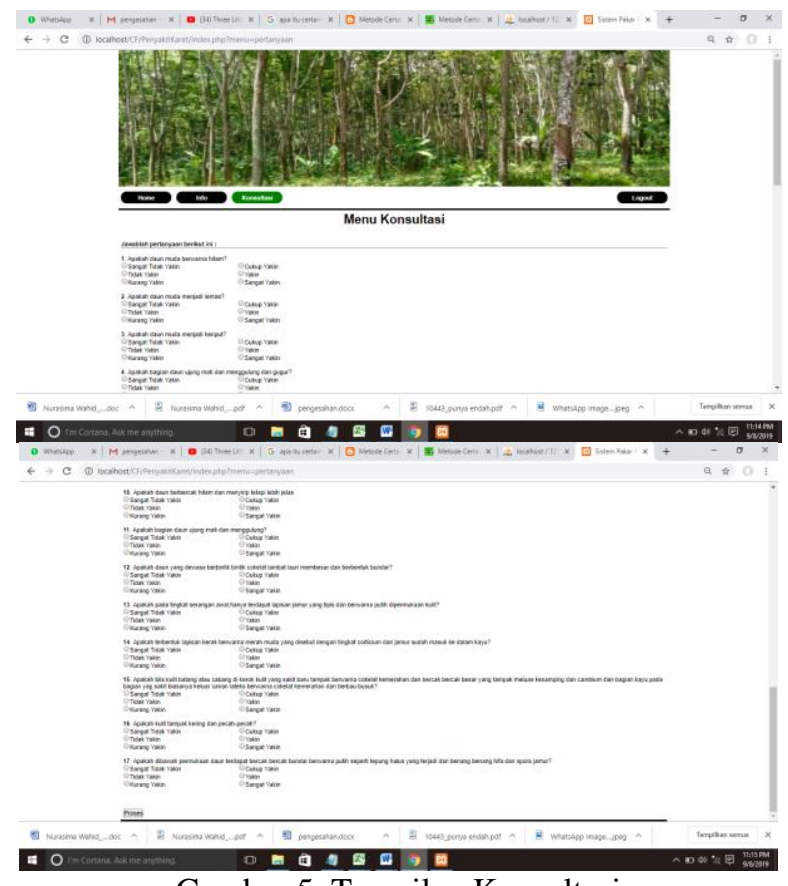

Gambar 5. Tampilan Konsultasi

\section{5) Tampilan Hasil}

Tampilan hasil adalah tampilan yang menampilkan hasil dari konsultasi yang menyimpulkan hasil penyakit dari hasil konsultasi yang telah diisikan sebelumnya.

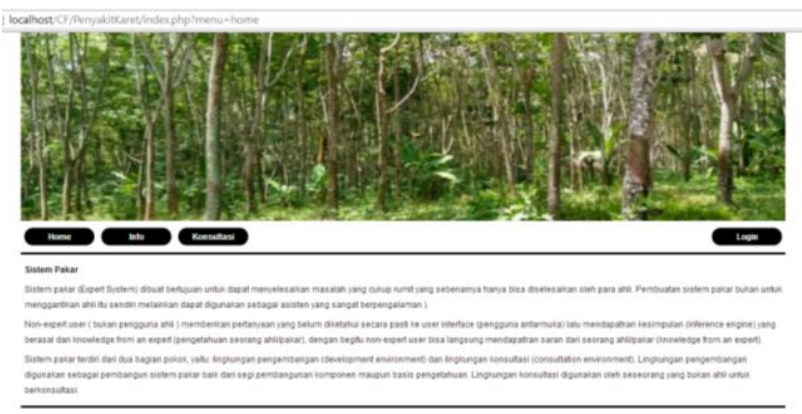

Gambar 6. Tampilan Hasil 


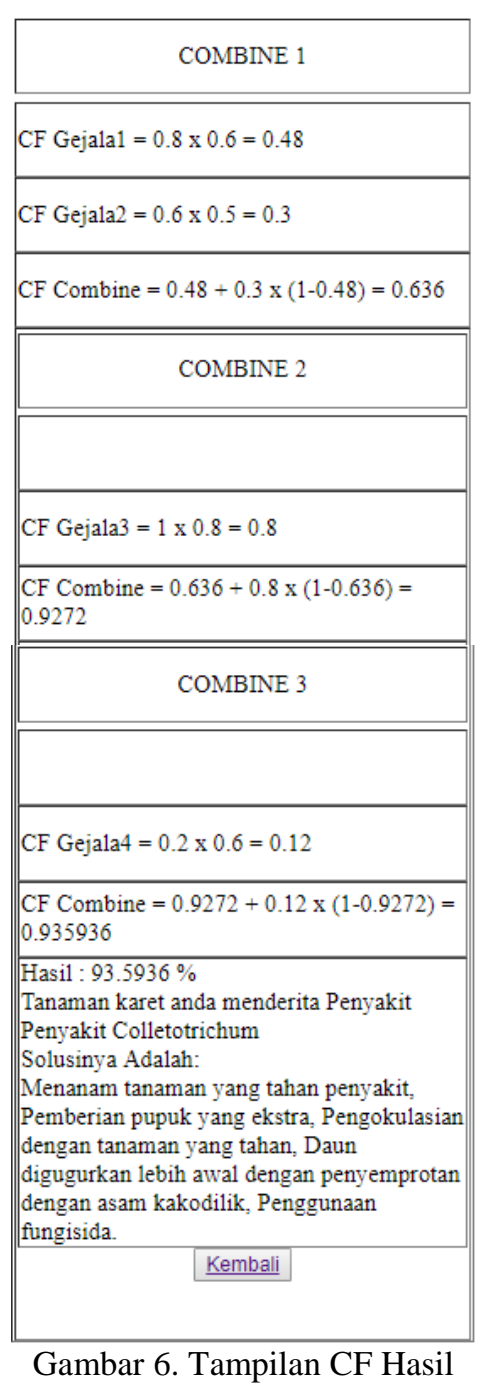

\section{KESIMPULAN}

Aplikasi ini dibangun berbasis web dengan menggunakan database My Structured Query Language dan Hypertext Preprocessor(PHP). Aplikasi ini menyediakan beberapa gejala penyakit daun dan batang pada tanaman karet. Kemudian pengguna melakukan konsultasi untuk mengetahui perhitungan hasil dari gejala penyakit dengan benar.

Pembuatan aplikasi ini masih dapat dikembangkan seiring dengan berkembangnya spesifikasi kebutuhan pengguna dan membuat tampilan aplikasi lebih menarik lagi. Pembuatan sistem ini diharapkan supaya bermanfaat bagi para petani tanaman karet dalam kehidupan sehari hari.

\section{DAFTAR PUSTAKA}

Anshori A.S. 2018 "Sistem Pakar Untuk Menentukan Pola Latihan Fitness Menggunakan Metode Certainty Factor". Samarinda:Manajemen Pertanian Politeknik Pertanian Negeri Samarinda.

Aprianti R. 2015. Mengenal Apa Itu XAMPP?. https://rantidiaapriyanti.wordpress.com (di unduh 30 September 2018).

Heminsyah. 2013. Sistem Pakar Penyakit Tanaman Karet Menggnakan Metode Dempster Shafer Berbasis Android. Pekanbaru. Fakultas Sains Dan Teknologi Universitas Islam Negeri Sultan Syarif Kasim Riau.

Hidayatullah P. dan Kawistara J.K. 2014. Pemrograman WEB. Informatika Bandung, Bandung. Hal 13.

Irwan N. 2016."Aplikasi Sistem Pakar Identifikasi Penyakit Pada Tanaman Padi Menggunakan Metode Certainty Factor". Malang:Fakultas Sains Dan Teknologi Universitas Islam Negri Maulana Malik Ibrahim Malang.

Maulana J.R, Fitriyadi \& Fitriani R. 2016.”Sistem Pakar Diagnosa Penyakit Tanaman Karet Dengan Metode Dempster Shafer". JUTISI Vol.5,No.1:1013-1021.

Miranda R, Hasibuan N.A, Pristiwanto \& Mesran. 2016."Sistem Pakar Mendiagnosa Penyakit Akar Putih (Riqidoporus Lignosus) Pada Tanaman Karet (hevea Brasiliensis) Dengan Metode Cetainty Factor". Jurnal Riset Komputer (Jurikom) Vol.3,No.6:124-127.

Mujilahwati S. 2017.’Diagnosa Penyakit Tanaman Hias Menggunakan Metode Certainty Factor Berbasis Web". Jurnal Teknik A. Vol.6,No.2:585-591.

Raghib N. 2013. Pengertian dan Defenisi WEB. http://raghibnururuddin217.blogspot .com (diunduh 30 September 2018).

Rahayu M.S, Lubis L \& Oemry S. 2017.’Distribusi Peta Awal Serangan Pnyakit Jamur Akar Putih (riqiduporus Lignosus Swartz:Fr) Pada Beberapa Perkebunan Karet Rakyat Diperkebuanan Asahan”. Jurnal Agroekoteknologi FP USU Vol.5,No1:131137.

Rasjid F.E. 2014. Bahasa Pemrograman Populer PHP. https://www.ubaya.ac.id (diunduh 30 September 2018).

Tarmizi H. 2017. Pengertian Sublime Text. https://hayantarmizi.blogspot.com. (diunduh 30 September 2018).

Zainab. 2017."Sistem Pakar Diagnosa Penyakit Tanaman Karet Menggunakan Metode Certainty Factor". Media Informatika Budidarma. Vol.1,No.3:67-70. 